\title{
MODEL PEMBELAJARAN BERORIENTASI FUNDAMENTAL DENGANPERMAINAN AIR UNTUK ANAK 5 - 6 TAHUN
}

\author{
WAHYUNINGTIAS PUSPITORINI ${ }^{1}$, RIZKI KURNIATI ${ }^{2}$, JAMES \\ TANGKUDUNG ${ }^{3}$ \\ POR PPs Universitas Negeri jakarta ${ }^{1}$ \\ Email:wahyuningtiaspuspitorini@unj.ac.id \\ Universitas Medan $^{2}$ \\ Email: Kyereen19@gmail.com \\ POR PPs Universitas Negeri jakarta ${ }^{3}$ \\ Email: jamestangkudung@unj.ac.id
}

\begin{abstract}
The purpose of this research are; (1) develop fundamental movement based learning using water games for children 5-6 years and (2) obtain empirical data on the effectiveness of the results of model development fundamental movement based learning using water games for children aged 5-6 years. Subjects in this study were children aged 5-6 years in kindergarten. Place of research conducted in the city of Palembang. This study is the development of the Research and Development of Borg and Gall. Product results of the research is a fundamental movement guidebook using water games. Research shows that: (1) the development of fundamental movement based learning using water games for children aged 5-6 years have been declared invalid by a motor learning, physical activity experts and practitioners of early childhood education, (2) fundamental movement based learning using water games proved $85 \%$ can improve fundamental skills and helps to build a sense of confidence and courage.
\end{abstract}

Keywords: fundamental movement, water games, children aged 5-6 years.

\begin{abstract}
Abstrak: Tujuan dari penelitian ini adalah; (1) mengembangkan pembelajaran berbasis gerakan fundamental dengan menggunakan permainan air untuk anak-anak 5-6 tahun dan (2) memperoleh data empiris tentang keefektifan hasil pengembangan model pembelajaran berbasis gerakan dasar dengan menggunakan permainan air untuk anak usia 5-6 tahun. Subjek dalam penelitian ini adalah anak usia 5-6 tahun di taman kanak-kanak. Tempat penelitian dilakukan di Kota Palembang. Penelitian ini merupakan pengembangan dari Penelitian dan Pengembangan menggunakan rancangan Borg dan Gall. Hasil produk penelitian ini adalah buku panduan pergerakan fundamental dengan menggunakan game air. Penelitian menunjukkan bahwa: (1) pengembangan pembelajaran berbasis gerakan fundamental dengan permainan air untuk anak usia 5-6 tahun telah dinyatakan tidak berlaku oleh pembelajaran motorik, ahli aktivitas fisik dan praktisi pendidikan anak usia dini, (2) pembelajaran berbasis gerakan dasar Menggunakan permainan air terbukti 85\% dapat meningkatkan keterampilan dasar dan membantu membangun rasa percaya diri dan keberanian.
\end{abstract}

Kata Kunci: gerakan Fundamental, Permainan air, Anak usia 5-6 Tahun

\section{PENDAHULUAN}

Aktivitas air diberikan sebelum anak belajar teknik berenang. Tahapan dalam membelajar anak-anak dalam air berupa gerakan awal, sikap, dan keamanan air untuk mempersiapkan anak belajar teknik berenang. Gerak dasar yang dimaksud adalah dasar 
untuk berenang, yaitu cara masuk ke dalam air, daya apung badan dalam air, pergerakan tungkai kaki, keseimbangan tubuh dalam air, gerak lengan, dan kontrol. dari nafas Sikap dasar yang ditetapkan melalui kegiatan pengenalan air adalah kemauan yang tinggi, menjalankan regulasi, dan berperan aktif. Pemahaman awal bahwa, anak-anak diharapkan memahami dengan baikkegiatan pengenalan air melalui prosedur kelas, peraturan kolam renang, regulasi permainan, arahan guru, dan melakukan gerakan dasar.

Aktivitas dalam kolam air telah menjadi program di beberapa pusat pendiidkan anak-anak baik pada tataran PAUD TK. Implementasi instruksional menggunakan kolam air renang sekolah untuk taman kanak-kanak yang memiliki fasilitas kolam renang. Taman kanak-kanak yang tidak memiliki kolam renang dapatmenyewa kolam renang umum. Hal ini menunjukkan bahwa baik guru TK maupun orang tua sadar akan kebutuhan mengenalkan siswa pada lingkungan bermain air. Ketika peneliti mewawancarai salah satu guru taman kanak-kanak ada sebuah pernyataan, "Permainan di air mengharuskan anak untuk melatih kepercayaan diri, selain itu anak bisa bermain asyik". Guru merasa perlu untuk mengatur aktivitas bermain air pada siswa untuk merangsang kepercayaan diri, keberanian, keseimbangan dan perkembangan sosial emosional.

Perkembanga nmodel pembelajaran gerak dasar dilengkapi dengan peraturan keselamatan untuk mengenalkan anak pada cara bermain dengan aman di air. Model pembelajaran berorientasi fundamental dengan permainan airyang telah dikembangkan ini diharapkan dapat memberikan referensi bagi para guru tentang variasi model pengenalan air sehingga memudahkan guru untuk menerapkan model pembelajaran gerak dasar berdasarkan permainan. Guru diharapkan bisa mengorganisir model dalam kegiatan belajar mengajar sehingga semua anak memiliki pengalaman bermain yang aman di dalam air.

Konsep pengembangan model adalah gagasan proses 
Model Pembelajaran Berorientasi...... Wahyuningtias, Rizki, \& James

pembangunan untuk menghasilkan sesuatu. Dalam penelitian dan pengembangan ini, ide yang akan dibuat atau diproduksi adalah sebuah buku, yang selanjutnya disebut model gerak gerak berbasis gerakan dasar. Model gerak berbasis gerakan gerak adalah permainan yang harus diatur secara berurutan sesuai kebutuhan anak, serta pola perkembangan anak.

Dengan menggabungkan dua gerakan atau lebih gerakan dasar seperti berjalan, berlari, melempar, melompat, dan berayun dapat meningkatkan kemampuan motorik anak-anak. Pengembangan keterampilan motorik pada anak usia 5-6 tahun melalui aktivitas fisik, seperti berlari, melompat, melempar dan aktivitas bermain lainnya yang menggunakan otot besar dan kecil. Pembelajaran fisik motorik sebagai salah satu rangsangan bagi anak untuk bisa bergerak aktif pada usia dan tahap perkembangan anak. Stimulasi pertumbuhan dan perkembangan pada anak usia 5-6 tahun dilakukan melalui permainan yang memberi kesempatan bagi anak untuk bergerak bebas. Konsep pengembangan pembelajaran berbasis gerakan dasar pada permainan air adalah dengan menggunakan air sebagai salah satu alat dalam proses permainan.

Air digunakan sebagai media yang baik dalam menstimulasi perkembangan anak baik dalam membangun kepercayaan diri, keterampilan motorik, koordinasi mata tangan, dan meningkatkan kebugaran. Konsep pengembangan model ini adalah dengan menggunakan alat sederhana, yang tersedia di lingkungan sekitar. Misalnya penggunaan balon, botol, baskom, pelampung, spons, bendera, dan alat lainnya yang bisa dimanfaatkan sebagai peralatan, kemudian dipadukan dengan game yang akan dikembangkan.

\section{KAJIAN TEORITIK}

Gerakan fundamental adalah dasar gerakan manusia yang terus tumbuh sesuai dengan pertumbuhan, pengalaman, adaptasi dan kematangan seseorang. Pendapat Gallahue (2011:12) menyatakan bahwa kemampuan gerak dasar, yaitu: "Gerakan tubuh total di mana 
tubuh didorong dalam postur tegak dari satu titik ke titik lain dalam arah horizontal atau vertikal, gerakan seperti berjalan, berlari, melompat, berlari, melompat, meluncur dan melompat ".

Menurut Magil (2011:76), pembelajaran motor adalah studi keterampilan motorik, meningkatkan kinerja belajar keterampilan motorik untuk meningkatkan pengalaman pergerakan, atau memulihkan keterampilan yang sulit dilakukan atau tidak bisa dilakukan karena cedera, sakit dan sejenisnya. Yang menarik adalah perubahan perilaku dan / atau neurologis yang terjadi pada seseorang sambil belajar keterampilan motorik dan variabel lain yang mempengaruhi perubahan.

Proses belajar motorik yang terjadi antara lain: (1) tahap penerimaan dan pengolahan masukan, (2) proses pengendalian dan keputusan, dan (3) kinerja keterampilan motorik. Ekspresi gerakan secara bertahap akan meningkatkan efektivitas dan stabilitas jika terus dilatih dengan frekuensi, intensitas, dan tempo yang sesuai. Tahap akhir dari proses belajar motor adalah tahap otonomi. Ciri panggung otonomi, yang sudah mapan gerak otomatis karena pelaku gerak telah menguasai keterampilan gerak. Pemikiran urutan gerak yag harus dilakukan tidak diperlukan agar aktor bisa menerima tugas lainnya. Keterampilan gerak masih memiliki kemungkinan untuk ditingkatkan. Latihan masih dibutuhkan pada tahap otonomi untuk meningkatkan kualitas gerak.

Bermain air memberikan manfaat sosial. Belajar permainan baru mengembangkan keterampilan anak-anak mendengarkan dan perkembangan kognitif. Permainan juga menyediakan lingkungan yang positif dalam membantu anak-anak bahkan anak yang pemalu, serta meningkatkan interpersonal anak. Berhasil berinteraksi dengan orang lain membantu anak memperoleh kepercayaan diri. Selain itu permainan yang membutuhkan anakanak untuk menggunakan imaginasi mereka mendorong peserta untuk mengekspresikan ide-ide dan berbagi kreativitas dengan orang lain. 


\section{METODE PENELITIAN}

Rancangan penelitian ini peneliti mengacu pada model pengembangan (penelitian dan pengembangan) Borg dan Gall. Dari sepuluh langkah tersebut ada beberapa yang dimodifikasi oleh peneliti sesuai kebutuhan. Langkahlangkah yang diambil Langkahlangkah yang diambil (1) Analisis kebutuhan dan pengamatan lapangan, (2) Rencana Penelitian yang dipersiapkan,

Perkembangan produk awal, (4) Uji coba, (5) Revisi produk awal, (6)) Uji lapangan utama (7) Produk revisi (8) Uji utama untuk melihat hasil efektifitas produk, (9) Revisi akhir dan (10) diseminasi dan pelaksanaan. Subjek penelitian adalah 6 siswa TK yang diambil dengan teknik random sampling. Jenis data yang dihasilkan berupa data kuantitatif dan data kualitatif. Data kualitatif berasal dari hasil data dari saran dan masukan ahli. Data kuantitatif menggunakan teknik analisis kuantitatif deskriptif dengan prosentase dan uji statistik $\mathrm{T}$ pada uji efektifitas produk. Subyek yang terlibat dalam pengembangan ini adalah sebagai berikut: (1) subjek sebagai studi pendahuluan (analisis kebutuhan) mewawancarai 15 guru dari tiga sekolah, (2) mata pelajaran evaluasi ahli yang terdiri dari 2 ahli motor, 3) Subjek tes adalah 20 anak dari TK Amalia, (4) Mata pelajaran lapangan adalah 60 anak dari dua sekolah, Mahardika dan PAUD Mandiri (5) mata pelajaran utama tes efektivitas adalah 80 anak dari tiga sekolah, TK Pembina, TK Ar-Raiha, dan Anak Usia Dini Sekolah pendidikan Dalam uji keefektifan uji yang digunakan adalah penilaian gerakan fundamental.

\section{HASIL DAN PEMBAHASAN}

Hasil pengamatan dan wawancara menunjukkan bahwa; tanggapan guru kelas tentang sebuah model pengenalan air diperkenalkan di kelas terdapat dua macam jawaban dari total 15 guru dari tiga sekolah, yaitu; Setuju dan tidak setuju. (1) jawaban pertama tidak setuju diberikan oleh 3 guru (20\%), sedangkan 12 guru (80\%) menjawab setuju.

Dari penjelasan diatas diperoleh pemahaman bahwa ada tiga kategori jawaban dari para 
pengguna, pertama yang menyatakan tidak setuju dengan jumlah responden tiga orang guru, dengan alasan susah dilakukan dan sangat beresiko pada keselamatan anakanak bermain di dalam air. Kedua,

Setelah melakukan pengumpulan data dan tahap penyusunan model pembelajaran berorientasi fundamental dengan permainan air, langkah selanjutnya adalah melakukan uji ahli. Berdasarkan uji ahli yang dilakukan dapat disimpulkan bahwa variasi model pembelajaran berbasis gerak dasar permainan air adalah layak dan dapat digunakan dan menghasilkan 28 variasi model pembelajaran.

Selanjutnya setelah 28 model direvisi dari ahli kemudian dilanjutkan dengan tes kecil dibatasi dengan menggunakan subjek penelitian sebanyak 20 anak yang berasal dari TK di Kota Palembang Berdasarkan evaluasi uji coba terbatas yang dilakukan dapat disimpulkan: 1) Persiapan tingkat kesulitan dimulai dari gerakan dan permainan dari yang mudah sampai yang tangguh, dari yang ringan sampai yang berat, dan sederhana ke kompleks. 2) optimalisasi waktu pelaksanaan dan keamanan. 3) jumlah gerakan dasar hingga 58 gerakan dan 28 permainan yang bisa dilakukan anak.

Para ahli mengenai pengembangan model pembelajaran yang telah diuji dalam pengujian lapangan, ternyata penggunaan model yang telah dikembangkan tidak perlu direvisi karena semua aspek sudah memenuhi standar yang akan digunakan. sehingga dapat dilakukan pengujian produk dengan menguji efektifitas dan efisiensi dalam proses pembelajaran.

Langkah selanjutnya Uji coba operasional (uji efektivitas) tes ini melibatkan khalayak yang lebih luas. Tujuan utama dari langkah ini adalah: seberapa efektif hasil penerapan disain model dengan tujuan penelitian. Penelitian pada tahap ini menggunakan pendekatan kuantitatif, dengan desain penelitian pra-eksperimental dalam bentuk desain pretest-postest satu grup.

Tabel 1. Desain Penelitian dalam Uji Efektivitas Model

\begin{tabular}{|c|c|c|c|}
\hline Subjek & Pra-tes & pengobatan & $\begin{array}{c}\text { Post- } \\
\text { test }\end{array}$ \\
\hline
\end{tabular}


Model Pembelajaran Berorientasi...... Wahyuningtias, Rizki, \& James

\begin{tabular}{|l|l|l|l|}
\hline $\mathrm{R}$ & $\mathrm{O}_{1}$ & $\mathrm{P}$ & $\mathrm{O}_{2}$ \\
\hline
\end{tabular}

Hasil uji efektifitas model yang dilakukan dalam penelitian ini adalah untuk melakukan tes kinerja pada 4 sekolah, yaitu: TK AR-Raihan, TK Negeri Pembina, dan PAUD Tunas Pertiwi, sebanyak 80 anak diberi perawatan dengan menggunakan model pembelajaran berbasis gerak dasar. Air untuk anak 5-6 tahun. Diberikan 5 pertemuan. Berikut ini adalah hasil uji efektivitas model (lihat tabel 2)

Persentase sebelum perawatan 15\% (12 anak) yang bisa mengikuti tes, sedangkan setelah diobati $\quad 85 \% \quad(68$ anak) yang berhasilmengikuti tes. Ini membuktikan bahwa model pembelajaran berbasis gerakan fundamental dari permainan air dapat mendekati target yang telah ditentukan dan tujuan permainan air ini tercapai.

Berdasarkan tabel berikut maka rata-rata skor skor tes berdasarkan pengamatan sebelum model pembelajaran dasar berdasarkan permainan air untuk anak usia 5-6 tahun adalah 7.2850 sebelum postest dan setelah diberi perawatan sampai kenaikan 9.5750 .

Tabel 2. Susunan Sampel berpasangan pre-test dan post-test

\begin{tabular}{|l|c|c|c|c|c|c|}
\hline & & & & & \multicolumn{1}{|c|}{$\begin{array}{c}\text { Std. } \\
\text { Kesalahan } \\
\text { berarti }\end{array}$} & $\%$ \\
\hline \multirow{2}{*}{ Pasangan 1 } & Pretest & 7.2850 & 80 & 6.76676 & .66992 & $15 \%$ \\
\cline { 2 - 7 } & Postest & 9.5750 & 80 & 8.25204 & .83042 & $85 \%$ \\
\hline
\end{tabular}


Tabel 3. Hasil Paired Samples Test Pre Test dan Post Tes gerakan fundamental dengan menggunakan permainan air untuk anak 5 - 6 tahun, maka dapat disimpulkan bahwa: Penelitian ini Uji Sampel Paired

\begin{tabular}{|c|c|c|c|c|c|c|c|c|c|}
\hline & \multicolumn{5}{|c|}{ Perbedaan berpasangan } & \multirow[b]{3}{*}{$\mathrm{t}$} & \multirow[b]{3}{*}{ df } & \multirow{3}{*}{$\begin{array}{l}\text { Sig. (2- } \\
\text { tailed) }\end{array}$} \\
\hline & & \multirow[b]{2}{*}{ Rata } & \multirow{2}{*}{$\begin{array}{c}\text { Std. } \\
\text { Deviasi }\end{array}$} & \multirow{2}{*}{$\begin{array}{c}\text { Std. } \\
\text { Kesalah } \\
\text { an } \\
\text { berarti }\end{array}$} & \multicolumn{2}{|c|}{$\begin{array}{c}\text { 95\% Interval } \\
\text { Kepercayaan Selisih }\end{array}$} & & & \\
\hline & & & & & Bawah & Atas & & & \\
\hline $\begin{array}{c}\text { Pasa } \\
\text { ngan } \\
1\end{array}$ & $\begin{array}{l}\text { Pretest - } \\
\text { Postest }\end{array}$ & $\begin{array}{c}3.850 \\
00\end{array}$ & 5.67502 & .76602 & 1.36125 & 4.33875 & 6.872 & 79 & .000 \\
\hline
\end{tabular}

Dalam uji signifikansi perbedaan dengan menggunakan SPSS diperoleh Mean $=3,850$ menunjukkan perbedaan pretest dan posttest, hasil $\mathrm{t}$ hitung $=6,872$, $\mathrm{df}=$ 79 dan $p$-value $=0,00<0,05$ yang berarti ada perbedaan yang signifikan antara sebelum dan sesudah adanya pengobatan. model pembelajaran gerakan dasar berbasis permainan air.

\section{KESIMPULAN DAN SARAN}

Berdasarkan hasil uji coba lapangan dan pembahasan hasil penelitian pembelajaran berbasis telah menghasilkan suatu produk buku berupa pembelajaran berbasis gerakan fundamental. menggunakan permainan air untuk anak-anak 5 - 6 tahun. Berdasarkan hasil uji efektifitas pembelajaran berbasis gerakan fundamental pada permainan air, terbukti bahwa hasil produk memiliki keefektifan yang sangat baik setelah perawatan. Hal ini bisa dilihat dari persentase keberhasilan $85 \%$ yang berarti 68 anak berhasil dalam tes yang diberikan. Hal itu juga bisa ditunjukkan dengan hasil ttest yang menunjukkan kenaikan yang sangat signifikan. Jadi, 
Model Pembelajaran Berorientasi...... Wahyuningtias, Rizki, \& James

pembelajaran berbasis gerakan fundamental menggunakan permainan air untuk anak-anak 5 - 6 tahun efektif untuk mencapai tujuan. Diharapkan para tenaga pendidik harus tenaga pendidik dilembaga pendidikan anak usia dini dapat: (1) Menggunakan buku model pembelajaran untuk kemajuan dan keberagaman model pembelajaran pada anak-anak PAUD; (2) Tenaga pendidik pada lembaga PAUD terus berbenah dalam pembelajaran dengan memahami model ini sebagai salah satu bahan yang bisa menginspirasi; (3) Calon tenaga pendidk (mahasiswa dari PAUD) terus mengexplorasi diri untuk mampu berkarya dalam dunia pendidikan seperti menghasilkan model pembelajaran; (4) Calon tenaga pendidik Khusus mahasiswa pascasarjana prodi PAUD, jangan menjauhi penekitian pengembangan; (5) Calon tenaga Pendidik mahasiswa pascasarjana prodi PAUD dapat menjadikan referensi untuk penelitian relevan

\section{DAFTAR PUSTAKA}

Gallahue \& Ozmun. Understanding Motor Development, $6^{\text {th }}$ ed. 